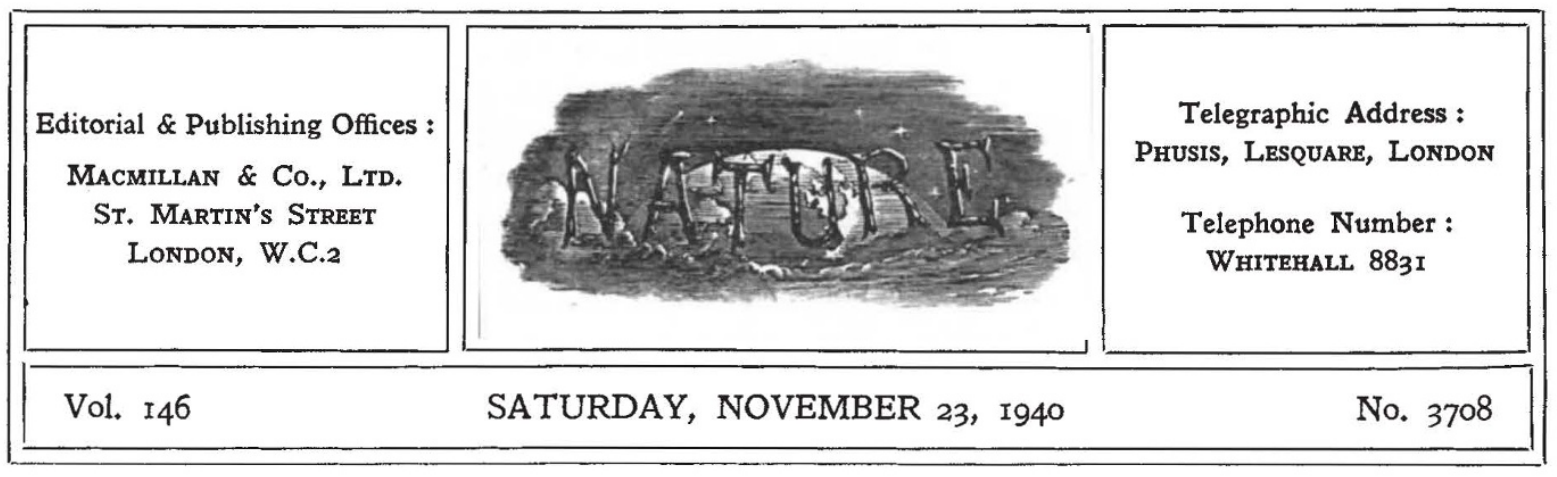

\title{
THE MINISTRY OF WORKS AND BUILDINGS
}

$\mathrm{I}^{\mathrm{N}}$ his speech to the Trades Union Congress on 1 October 9, Mr. Ernest Bevin stated that the Cabinet had decided against the establishment of a Ministry of Reconstruction to consider the problems of the peace and to prepare plans for meeting them. Instead, a Cabinet committee has been set up to consider post-War questions and to work out general principles for guidance. There will be many who think that Mr. Bevin did less than justice to the work of the Ministry of Reconstruction established under Dr. (now Lord) Addison in 1917. Whether we hold that the task of preparing for the future should be the task of a special Ministry of Reconstruction or, as suggested by Prof. J. H. Jones, of an Economic Reconstruction Commission, the task is clearly that of the Cabinet, and the gravest danger to be avoided is that of hasty improvisation by war-weary Ministers in control of departments that have been overburdened by the urgent tasks imposed by the War.

The appointment of Lord Reith to the new office of Minister of Works and Buildings and First Commissioner of Works is, however, indication that the Government recognizes more fully than Mr. Bevin's speech would imply the magnitude of the task which lies ahead. The general approval with which the creation of this new office was received may indeed be attributed to the assumption that its task was to be almost wholly that of reconstruction-immediate and local in bombed areas, theoretical and general as regards national replanning and rebuilding after the War. These expectations were somewhat disappointed by $\mathrm{Mr}$. Attlee's statement on October 24 regarding the functions of the new Ministry, and by Lord Reith's own statement in similar terms on November 13 in the House of Lords. Wide as are the functions of the new Ministry, they do not inspire the vision of a new England of well-designed, clean and slumless towns, an architecture of public buildings and private homes justifying civic and personal pride, the wise and creative use of the new materials and the planning of communications and industrial and other building to safeguard æsthetic and health values as well as serve efficiency.

The two statements were largely confined to the war-time duties of the Ministry and the alterations in departmental responsibilities. The new Ministry will be responsible for the erection of all new civil works and buildings required by any other Government department. It will take over the whole organization of His Majesty's Office of Works, including its present responsibilities for the erection of buildings for other civil departments and for service departments, and some of the work of the Ministry of Supply, including the new buildings section of the Ordnance Factories and the approval of plans of new private factories or the extensions of existing private factories to the cost of which the Ministry of Supply is contributing. The Ministry will be responsible for the licensing of private building, and for determining the priority of proposals for rebuilding buildings damaged by air raids. By arrangement with the service departments or the Ministry of Aircraft Production it may erect on their behalf new works and buildings not of a highly specialized character, or supervise contracts for the erection of new private factories or the extension of existing private factories required for war production.

The general order of priority of building work will be laid down by the Production Council, of which the Minister will be a member, and he will be. responsible for the Works and Buildings Priority 
Committee. The Minister will be empowered to call for information from all departments retaining responsibility for the erection and maintenance of buildings and works of construction, including departments concerned with work carried out by or for local authorities and public utility undertakings. He will also be responsible for such control, or central purchase of building materials not at present controlled, as may be necessary. The Minister will also have the task of instituting research into such questions as the adoption of substitutes for building materials which are in short supply, or the modification of designs and specifications with a view to expedition and for ensuring that the results of past and future research are promptly communicated to all concerned. For this purpose he will make full use of the building research organization of the Department of Scientific and Industrial Research. $\mathrm{He}$ will be empowered to call on Departments retaining responsibility for building to satisfy him that they were making full use of the results of research in this connexion.

This statement shows that the Ministry of Works and Buildings clearly envisages the great possibilities open to the building industry, architects and town-planners ; first, the control by a single authority of the production and allocation of all building resources for the period of the War; secondly, the continuance of the Ministry's control after the War so that building resources may be carefully guided in supplying a huge demand; and thirdly, the post-War amalgamation of the Ministry and the Town-Planning Section of the Ministry of Health to evolve and direct positive territorial planning policy. Even should the first of these functions absorb all the energies of the Ministry for the first year, if its powers are exercised with wisdom and foresight, many undesirable developments may be checked and much important preparatory work for reconstruction completed.

The Ministry of Works and Buildings is clearly the only right remedy for the serious difficulties which have arisen from the shortage of certain materials, plant, etc., and the even bigger diffculties in the production of building materials of the required kinds and their allocation between war expansion requirements, air raid repairs to communications, services and essential buildings, general works of maintenance, civil defence works and such other works as are made necessary by bombing. Its duties as outlined by Lord Reith falling into the three divisions, supervision, execution and research, provide the essential co-ordination of resources and should secure the full cooperation of the industries concerned.

An important memorandum recently forwarded by the Garden Cities and Town Planning Association to the Prime Minister and other ministers concerned with the use of land, outlining a practical policy with regard to bombed-out factories, rebuilding and replanning damaged areas, housing, compensation and the preservation of land for food-growing, urges that the control of war-time developments of industry or rehousing exercised by the Ministry should be through a fully qualified planning board, competent to consider and to balance all the national interests that arise in new developments. The present situation indeed stresses the importance of the principles and recommendations of the Barlow Commission, and adoption of the principle of long-range planning by the Government is a first consideration even from the point of view of the building industry alone. Indeed only by insisting on the duty of forecasting, by programmes obtained from all other departments, the total demand on the building industry at least a year ahead and preparing resources to meet those demands in the light of probable shortages of important materials, can the Ministry hope to discharge its most immediate task.

Beyond those immediate problems there must be kept in mind those broad principles which have emerged from inquiries into the distribution of the industrial population in recent years. To limit the size and density of cities, to move out congested industries to moderate-sized well-planned towns, including some new garden cities; and to replan and rebuild the central parts of old cities, with much more open and garden space and more attention to convenience and beauty, and the elimination of wasteful daily travel so far as possiblethese are now practical objectives the achievement of which is even assisted by the destruction already caused by air attack.

The new Ministry may indeed offer us the first prospect of the co-ordination leading to a comprehensive far-sighted national plan of development. Mr. Attlee's statement showed that the Government is alive to the great opportunities which are offered in the reconstruction of town and country after the War. The Minister has been charged with the responsibility of consulting the departments and organizations concerned, with the view of reporting to the Cabinet the appropriate 
methods and machinery for dealing with the issues involved. The relation of the Ministry of Works and Buildings to the existing machinery for statutory planning must obviously be very close. Accordingly the memorandum from the Garden Cities and Town Planning Association suggests that the best solution of the administrative problem will ultimately be the creation of a Ministry of Planning (or of Planning and Building), to absorb the functions of controlling building and of directing the statutory planning machinery, and to formulate a broad national policy for the distribution of industry which would be operated through the regional and local committees.

The memorandum also submits that the National Advisory Planning Board should consider which of the areas now subject to heavy bombardment are in themselves reasonably satisfactory from a planning point of view and not unduly congested, and which of them are so badly planned or so congested that replanning is advisable. In the former areas there should be no ban on rebuilding or repair at the earliest safe moment, subject to local architectural and planning control and given the necessity of accommodation locally and the approval of the Ministry of Works and Buildings from the point of view of the availability of materials and labour. In the unsatisfactory areas, however, it is strongly urged that wholesale expenditure on restoration or rebuilding should be deferred and the population evacuated to other areas, including those where new factories are being erected. Sir Charles Bressey, whose report on London's transport deserves fresh attention, has independently also entered a plea that no schemes of rehabilitation in bombed areas should go forward without reference to accepted principles and standards for the improvement of London's streets and buildings.

The complexities and possibilities of the problems confronting the new Ministry are indeed immense. They involve the question of evacuation, which, in respect of mothers and young children, is largely a question of the provision of suitable accommodation in the reception areas, part at least of which will involve new construction or the structural adaptation of existing premises. There is also the question of providing alternative accommodation of industries which may need to be dispersed from London and certain other large cities if the destruction of property and dislocation of transport and other public services becomes acute. This involves not merely the provision of a reserve of new factories in suitable situations but also the provision of housing accommodation for industrial workers engaged on war production or the service of the civil population, possibly involving a priority system in the smaller towns.

Moreover, not even in war-time can we neglect the control of building in agricultural areas. Sporadic or ill-considered building has already robbed the country of valuable agricultural land when alternative siting on land less valuable for food production could readily have been found. The criticism of the Select Committee on the neglect of camouflage possibilities in choosing sites could equally apply to neglect of agricultural or food production values. Moreover, some of the worst offenders have been the service departments over whose activities in respect of aerodromes, fortifications and other highly specialized work the Ministry of Works and Buildings will have no control.

Nor is it only on these grounds that there are well-founded fears as to whether the functions and powers of the new Ministry are sufficiently extensive. The work of rebuilding is indeed only a small part of the task of reconstruction awaiting us. That reconstruction will reshape many ways of life and will attack poverty and slumdom, ignorance and ill-health, the insecurities of employment, the closed doors of opportunity. It involves nothing less than the replanning of the national life, and if the Ministry of Works and Buildings is to have any real powers in planning and reconstruction, it must take over much of the present work of the Ministry of Health-especially its housing and planning departments. Besides close relations with the local authorities and with all the technical and professional bodies connected with building, the new Ministry must undertake a large task of education.

We can only hope to build a better order in any sense of the word in so far as both the population and their leaders are prepared for it. Educational work of this type is essential if our younger architects with vision and understanding are to be given the opportunity to express the possibilities of the new materials and to seize the new opportunities of serving social needs. It is equally a preliminary to securing the firm direction from the top to override anarchic interests. If the execution of such a programme of education lies outside the scope of the new Ministry, something at least of the inspiration is to be looked for from it. 